\title{
UTILIZATION OF DISTILLERS DRIED GRAINS WITH SOLUBLES IN FISH NUTRITION 2-PARTIAL REPLACEMENT OF FISH MEAL AND YELLOW CORN BY GRADED LEVELS OF DDGS IN NILE TILAPIA FINGERLINGS DIETS ( Oreochromis niloticus).
}

Gabr, A. A. ; F. F. Khalil and Samah E. M. El-Sharkawy

Dept. Animal Production, Fac. Of Agric., Mansoura University, Egypt

\begin{abstract}
This study was conducted to evaluate the effect of feeding different levels of DDGS in the diets of tilapia fingerlings on growth performance, feed utilization, chemical composition of the whole fish body, blood hematological and economic efficiency. Therefore, six graded levels of DDGS (0, 4, 8, 12, 16 and 20\%) were used insteated of fish meal and yellow corn protein in sex tested diets approximately isonitrogenous and isocaloric. Fish were stocked in a rearing plastic tank for two weeks adaptation period, then it were stocked at the rate of 5 fish/glass aquarium with initial weight of $6.0 \pm 0.14 \mathrm{~g} /$ fish. During the experimental period (72 days) the fish were fed the tested diets at the rate of $6 \%$ of the total biomass for six days per week. The obtained results showed that:

There were significant $(P \geq 0.05)$ effect of DDGS levels on all traits of growth performance and feed utilization parameters of Nile tilapia fed different levels of DDGS. All growth performance parameters were increased significantly $(P \leq 0.05)$ with increasing the replacement levels of DDGS until $16 \%$ of DDGS, then, decreased significantly with increasing the replacement level of DDGS. The highest values of growth performance parameters were found in replacement levels $16 \%$ of DDGS. The best values of economic efficiency recorded with the level $12 \%$ and $16 \%$ of DDGS, respectively. It may be concluded that replacing fish meal and yellow corn by DDGS until $16 \%$ in the diets of tilapia had no any adverse effect on most of growth parameters, feed utilization, chemical composition of fish body, hematological blood parameters and economic efficiency of tilapia fingerlings.

Keywords : DDGS, Nile tilapia, fish meal, growth performance, hematological blood, economic efficiency.
\end{abstract}

\section{INTRODUCTION}

The DDGS are primary residues from yeast fermentation of cereal grains and are a by-product of the bourbon and ethanol distilling process. These by-products contain approximately $26-28 \%$ protein, closely matching the protein requirements of tilapia (25-35\%) (Lim, 1989). Compared with many species, tilapia can utilize relatively high levels of plant feedstuffs (Twibell and Brown 1998). Also, Wu, et al. (1996) evaluated inclusion of DDGS at $30 \%$ of the total diet fed to tilapia and reported good growth parameters. However, research has shown that by combining complimentary animal and plant protein sources, nutrient utilization can be improved (Webster, et al., 1992 a\&b; Brown, et al 1997 and Webster, et al .,2000).

With the rapidly growing aquaculture industry, the demand for high quality fish feeds is increasing. At the current and expected aquaculture growth rates, the demand will eventually outgrow the availability of fish meal 
Gabr, A. A. et al.

as highly digestible protein source (Hardy, 2010). As a consequence the inclusion levels of plant derived proteins are increasing for formulated fish and crustacean feeds. However these plant derived ingredients have, in comparison to fish meal, a serious drawback since they always contain one or more anti-nutrients such as like protease inhibitors, lectins, gossypol, phytic acid, tannins or saponins (Francis et al., 2001). Since diet costs account for over $50 \%$ of production costs for most aquatic species, one way to increase production profitability is to reduce diet costs. Protein is generally the most expensive dietary component; therefore, determination of lessexpensive sources of protein which provide good growth is advantageous for diet manufacturers and aquaculture producers. Other factors including inconsistent supply and environmental concerns with using fish meal in aquaculture diets make evaluation of alternative protein sources a high priority for fish nutritionists. Tilapia diets without fish meal have generally reduced growth under intensive culture conditions (Jackson, et al., 1982 and El-Sayed, 1990).

Therefore, influence of feeding different levels of DDGS ( by reduce the percent of fish meal and yellow corn in tested diets ) on growth performance, feed utilization, chemical composition of the whole fish body, blood hematological parameters and economic efficiency of tilapia (Oreochromis niloticus) fingerlings was the aim of this study.

\section{MATERIALS AND METHODS}

\section{Experimental fish and conditions:}

This research was carried out at Fish Laboratory Research, Animal Production Department, Faculty of Agriculture, Mansoura University, Egypt, during the period from December, 2008 to March, 2009. The fish were stocked in a rearing tank for adaptation two weeks preconditioning period, then fed with the tested diets. A total numbers of 90 fingerlings weighted $6 \pm$ $0.14 \mathrm{~g} /$ fish that appeared healthy before its stocking at $5 \mathrm{fish} / \mathrm{glass}$ aquarium $(90 \times 40 \times 50 \mathrm{~cm})$ as three replicates per treatment were randomly assigned to the sex tested diets (D1 to D6). Each aquarium was supplied with $108 \mathrm{~L}$ dechlorinated tap water, electric heater and an air stone connected with electric small compressor to permit suitable level of dissolved oxygen. The dissolved oxygen was in normal range $(6-8 \mathrm{mg} / \mathrm{L})$. The replacement of the aquaria water was done partially every day to re-new the tap water after removing the wastes. Light was controlled by a timer to provide a 14h light: $10 \mathrm{~h}$ dark as a daily photoperiod.

\section{Experimental diet and feeding:}

Six experimental diets were formulated (D1 - D6) to replace DDGS at the rate of $0,4,8,12,16$ and $20 \%$ instead of fish meal (FM) and yellow corn protein. The DDGS used contained $26.84 \%$ crude protein, $11.08 \%$ crude fat, $6.30 \%$ crude fiber, $10.20 \%$ moisture and $4.24 \%$ ash. The ingredients and chemical composition of diets are shown in Table (1).

All diets except the control diet were supplemented with methionine to cover the needed level of this amino acid in all diets. The control diet 
(without DDGS) was formulated to contain $27.82 \%$ CP. All ingredients and additives were milled and mixed, then pressed through a pelleting machine (pellets size $1 \mathrm{~mm}$ ). During the experimental period (72 days), the fish were fed daily on the previous diets at a rate of $6 \%$ of the live biomass for six days a week and twice daily at $8 \mathrm{am}$ and $2 \mathrm{pm}$. The amount of feed was adjusted bi-weekly based on the actual body weight changes.

Table (1): Formulation (\%) and chemical analysis of the tested diets on dry matter basis

\begin{tabular}{|c|c|c|c|c|c|c|}
\hline Ingredients (\%) & $\begin{array}{c}\mathrm{D} 1 \\
\text { (control) }\end{array}$ & D2 (4\%) & D3 (8\%) & D4 (12\%) & D5 (16\%) & $\begin{array}{c}\text { D6 } \\
(20 \%)\end{array}$ \\
\hline Fish meal & 20 & 18 & 16 & 15 & 13 & 11 \\
\hline Soybean meal & 32 & 32 & 33 & 33 & 34 & 34 \\
\hline DDGS & 0 & 4 & 8 & 12 & 16 & 20 \\
\hline Yellow corn & 26 & 24 & 21 & 18 & 16 & 13 \\
\hline Wheat bran & 10 & 10 & 10 & 10 & 9 & 10 \\
\hline Corn oil & 6 & 6 & 6 & 6 & 6 & 6 \\
\hline Molasses & 5 & 5 & 5 & 5 & 5 & 5 \\
\hline${ }^{\star}$ Vit. and Min. premix & 1 & 0.7 & 0.7 & 0.7 & 0.7 & 0.7 \\
\hline Methionine ( $\mathrm{g} / \mathrm{kg}$ diet) & - & 0.3 & 0.3 & 0.3 & 0.3 & 0.3 \\
\hline \multicolumn{7}{|l|}{ Chemical analysis (\%) } \\
\hline Dry Matter & 90.64 & 89.79 & 90.35 & 87.34 & 86.74 & 88.77 \\
\hline Ash & 11.40 & 9.41 & 8.30 & 8.54 & 10.10 & 8.73 \\
\hline Crude Protein & 27.82 & 27.45 & 27.82 & 27.95 & 28.18 & 28.17 \\
\hline Crude fat & 6.13 & 5.74 & 5.01 & 5.01 & 5.75 & 6.32 \\
\hline Total carbohydrates & 54.65 & 57.40 & 58.87 & 58.50 & 55.97 & 56.78 \\
\hline $\begin{array}{l}\text { Gross energy (GE)(Kcal/100 } \\
\text { g DM) }\end{array}$ & 439.91 & 445.47 & 446.73 & 450.07 & 443.80 & 452.46 \\
\hline $\begin{array}{l}\text { Protein/ energy (P/E) ratio } \\
(\mathrm{mg} \mathrm{CP} / \mathrm{Kcal} \mathrm{GE})\end{array}$ & 63.24 & 61.62 & 62.27 & 62.10 & 63.49 & 62.25 \\
\hline
\end{tabular}

*Vitamin and minerals premix containing A vit. (15 million I.U.), E vit. (15 mg), B1 vit. (1.0 $\mathrm{mg})$, B12 vit. $(5.0 \mathrm{mg})$, K3 vit. $(2.5 \mathrm{mg})$, B6 vit. $(2.0 \mathrm{mg})$, Pantothenic acid (10.0 mg), Folic acid (1.2 mg), Biotin (0.05 mg) and D3 vit. (3.0 million I.U.). Copper (7.0 mg), manganese (100.0 mg), iodine (0.4 mg), Iron (40.0 mg), Zinc (50.0 mg), Selenium (0.15 $\mathrm{mg})$ and antioxidant (125.0 mg). * GE (Kcal/100 g DM) = CP x 5.64 + EE x 9.44 + Carbohydrates x 4.12 calculated according to (NRC, 1993).

${ }^{\star *} \mathrm{P} / \mathrm{E}$ ratio (mg protein/Kcal gross energy) $=\mathrm{CP} \times 1000 / \mathrm{GE}$

Water temperature $\left({ }^{\circ} \mathrm{C}\right)$ was recorded every two days by using a thermometer, and water $\mathrm{pH}$-value was measured weekly using an electric digital $\mathrm{pH}$ meter model (Jenway Ltd, model 350-pH meter). Aeration provided continuously using an air stone connected with electric small compressor and water temperature was thermostatically controlled on $27 \pm 1^{\circ} \mathrm{C}$ throughout the experimental period. Dissolved oxygen was measured every day in each aquarium using an YSI model 58 oxygen meter. During the 72 days of experiment, means of water quality parameters were temperature $26-27 ; \mathrm{pH}$ $7.4 \pm 0.6$; and dissolved oxygen $(6-8 \mathrm{mg} / \mathrm{L})$. At the end of the experimental period, fish sample were taken and dried at $70 \stackrel{\circ}{ } \mathrm{C}$ for 24 hours and passed through mincer into one composite homogenate per group. Contents of the homogenized fish for each experimental diet were analyzed chemically using the methods described by Association of Official Analytical Chemists (A.O.A.C. 2000). Also, at the end of the all rearing periods, three fish per 
Gabr, A. A. et al.

replicate within treatment were randomly chosen then individually weighed. Livers and intestine were removed, then it weighed to determine hepatosomatic index ( $\mathrm{HSI})$ and intestine somatic index (ISI) as follow:

$\mathrm{HSI}=($ Liver weight/ fish weight $) \times 100$ (Jangaard, et al., 1967)

$|S|=($ intestine weight/fish weight $) \times 100$

At the end of the experiment, blood samples were collected from all residual fish from caudal peduncle of the different groups. Adequate amounts of whole blood in small plastic vials containing heparin were used for the determination of hemoglobin $(\mathrm{Hb})$ by using commercial kits (Diamond Diagnostic, Egypt) and the hematocrit (PCV\%) was measured according to Stoskopf (1993). Total erythrocytes (RBCs) and total leukocytes (WBCs) were counted according to Dacie and Lewis (1995) on an Ao Bright - Line Haemocytometer model (Neubauer improved, Precicolor HBG, Germany). The obtained data were statistically analyzed using general linear models procedure according to SAS (2006) for users guide, with a one - way ANOVA. Means of treatments were statistically compared for the significance $(p \leq 0.05)$ using Duncan (1955) multiple range test.

\section{RESULTS}

\section{Growth performance parameters:}

Data in Table (2) showed that all growth performance parameters were increased significantly $(P \leq 0.05)$ with increasing the levels of DDGS until $16 \%$, then, it was decreased significantly with increasing the level of DDGS up to $20 \%$. However, no significant differences were recorded between the control diet and the replacement level $20 \%$. The highest values of growth performance parameters were found in diet 5 at the replacement levels $16 \%$ of DDGS. There were no significant differences were recorded in survival rate of tilapia fed the six experimental diets (D1-D6). Generally, survival rate was high and ranged from 90 to $100 \%$ in the most treatments in the present study.

\section{Feed utilization parameters:}

As shown in Table (3) there were no significant differences in feed intake (FI) among different DDGS levels were observed. On the other hand, the FCR improved significantly with increasing level of DDGS up to $16 \%$. While the other feed utilization parameters (FE, PER, PPV and EU) were decreased significantly $(P \leq 0.05)$ with increasing replacement of DDGS until $8 \%$ level then increased with increasing levels of DDGS until $16 \%$. The level $16 \%$ DDGS gave the best values of feed conversion ratio (FCR) and the highest values of feed utilization parameters (FE, PER, PPV and EU). The highest PPV and EU\% were recorded with 12\% DDGS level.

\section{Chemical composition of the whole fish body:}

The results in Table (4) indicated that the percentage of dry matter and crude protein of fish body were decreased significantly $(P \leq 0.05)$ with increasing DDGS levels. Crude fat $(\%)$ was increased significantly $(P \leq 0.05)$ by increasing of DDGS levels up to $16 \%$ compared with the control diet. Crude protein was significantly $(P \leq 0.05)$ differed among treatments. The 
highest value of DM \% and EC was observed in fish fed the level of $12 \%$ DDGS, while the highest value of crude fat and ash were observed at level $4 \%$ of DDGS. The highest value of crude protein $\%$ was observed in the control diet and the level $8 \%$ DDGS.

Table (2): Effect of feeding different levels of DDGS on growth performance parameters for Nile tilapia fingerlings

\begin{tabular}{|c|c|c|c|c|c|c|c|c|}
\hline \multirow{2}{*}{ Traits } & \multicolumn{6}{|c|}{ Level of (DDGS\%) } & \multirow{2}{*}{ SE } & \multirow{2}{*}{$\mathrm{Pr}>\mathrm{F}$} \\
\hline & 0 & 4 & 8 & 12 & 16 & 20 & & \\
\hline IW (g) & 5.88 & 6.04 & 5.87 & 6.08 & 5.93 & 6.05 & 0.02 & 0.098 \\
\hline $\mathrm{FW}(\mathrm{g})$ & $28.25^{c}$ & $\underset{d}{28.30^{b c}}$ & $28.44^{\mathrm{bc}}$ & $29.53^{a b}$ & $31.80^{\mathrm{a}}$ & $28.48^{b c}$ & 0.938 & 0.019 \\
\hline TWG (g) & $22.37^{\mathrm{bc}}$ & $19.85^{c}$ & $22.47^{\mathrm{bc}}$ & $23.45^{\mathrm{ab}}$ & $25.87^{a}$ & $22.43^{\mathrm{bc}}$ & 0.935 & 0.018 \\
\hline $\begin{array}{l}\text { ADG (g/ fish/ } \\
\text { day) }\end{array}$ & $0.319^{b c}$ & $0.283^{c}$ & $0.321^{b c}$ & $0.335^{\mathrm{ab}}$ & $0.369^{a}$ & $0.320^{b c}$ & 0.013 & 0.018 \\
\hline RGR (\%) & $380.3^{\mathbf{b}}$ & $328.7^{c}$ & $382.8^{b}$ & $385.6^{\mathbf{b}}$ & $436.2^{a}$ & $370.7^{\text {bc }}$ & 8 & 13 \\
\hline Gn & $2.23^{b}$ & $2.07^{c}$ & $2.24^{b}$ & $2.25^{\mathrm{ab}}$ & $2.38^{a}$ & $2.21^{b c}$ & 0.046 & 0.012 \\
\hline Survival (\%) & 90 & 95 & 100 & 90 & 100 & 100 & 0.564 & 0.865 \\
\hline
\end{tabular}

Means I $n$ the same rows having different small letters differ significantly $(P \leq 0.05)$. AWG $(g / f i s h)=[$ Average final weight $(g)$-Average initial weight $(g)]$. ADG $(g / f i s h /$ day $)=$ [AWG (g)/experimental period by days (d)]. RGR = 100 [AWG (g)/Average initial weight (g)]. SGR $(\% /$ day) = 100 [In final body weight - In initial body weight]/ experimental period by days (d). SR = 100 [Total No. of fish at the end of the experimental/Total no. of fish at the start of the exsperiment]. (Initial weight (IW), final weight (FW), total weight gain (TWG), average daily gain (ADG), relative growth rate (RGR) and specific growth rate $(\mathrm{SGR}))$. SE = Standard Error $\quad \mathrm{Pr}>\mathrm{F}=$ Probability value

Table (3): Feed utilization parameters of Nile tilapia fingerlings fed different levels of DDGS

\begin{tabular}{|c|c|c|c|c|c|c|c|c|}
\hline \multirow{2}{*}{ Traits } & \multicolumn{6}{|c|}{ Levels of (DDGS)\% } & \multirow{2}{*}{ SE } & \multirow{2}{*}{$\mathrm{Pr}>\mathrm{F}$} \\
\hline & $\mathbf{0}$ & 4 & 8 & 12 & 16 & 20 & & \\
\hline $\mathrm{FI}(\mathrm{g}) / \mathrm{d}$ & 48.83 & 46.25 & 52.18 & 46.14 & 48.11 & 47.75 & 1.733 & 0.227 \\
\hline FCR & $2.65^{a}$ & $2.32^{\mathrm{ab}}$ & $2.33^{a b}$ & $1.96^{b c}$ & $1.86^{\mathrm{c}}$ & $2.12^{\mathrm{ab}}$ & 0.07 & 0.002 \\
\hline FE (\% & $45.79^{c}$ & $43.03^{c}$ & $42.95^{c}$ & $51.04^{\mathrm{ab}}$ & $53.75^{a}$ & $46.97^{b c}$ & & 02 \\
\hline PEF & $1.64^{\mathrm{b}}$ & $1.56^{\mathrm{b}}$ & $1.54^{\mathrm{b}}$ & $1.89^{a}$ & $1.90^{\mathrm{a}}$ & $1.66^{b}$ & 0 & 77 \\
\hline PPV & $21.82^{\mathrm{ab}}$ & $18.85^{c}$ & $19.76^{b c}$ & $24.40^{a}$ & $22.66^{a}$ & $19.62^{b c}$ & 0.813 & 0.003 \\
\hline U (\%) & $12.63^{b}$ & $12.03^{b}$ & $11.57^{\mathrm{b}}$ & $15.77^{a}$ & $14.79^{a}$ & $11.83^{b}$ & 0.459 & $<.0001$ \\
\hline
\end{tabular}

Means in the same rows having different small letters differ significantly $(P \leq 0.05)$.

$\mathrm{FCR}=$ Feed Intake, (g)/ weight gain (g). FE = 100 [Live weight gain (g)/Feed Intake, $(\mathrm{g})$ ].

PER = Live weight gain (g)/protein intake (g). PPV $(\%)=100$ [Final fish body protein

content $(\mathrm{g})$ - Initial fish body protein content $(\mathrm{g})] /$ crude protein intake $(\mathrm{g})$.

EU $(\%)=$ Retained energy $\times 100 /$ consumed feed energy. 
Gabr, A. A. et al.

Table (4): Chemical composition on dry matter basis of the whole fish body components of Nile tilapia fingerlings fed different levels of DDGS

\begin{tabular}{|c|c|c|c|c|c|}
\hline \multirow[b]{2}{*}{ Treat. } & \multirow[b]{2}{*}{ DM \% } & \multicolumn{4}{|c|}{$\%$ On Dry matter basis } \\
\hline & & CP (\%) & EE (\%) & Ash (\%) & $\begin{array}{c}\text { EC (Kcal/100 } \\
\text { g) }\end{array}$ \\
\hline \multicolumn{6}{|c|}{ At the start of the experiment } \\
\hline & 18.48 & 56.99 & 19.81 & 23.20 & 508.4 \\
\hline \multicolumn{6}{|c|}{ At the end of the experiment } \\
\hline \multicolumn{6}{|c|}{ Levels of DDGS\% } \\
\hline 0 & $20.70^{b}$ & $61.30^{a}$ & $20.96^{d}$ & $17.73^{\mathrm{bcd}}$ & $543.63^{c}$ \\
\hline 4 & $20.67^{c}$ & $56.54^{\mathrm{d}}$ & $24.45^{\mathrm{a}}$ & $19.01^{\mathrm{a}}$ & $549.73^{b c}$ \\
\hline 8 & $20.19^{d}$ & $60.93^{a}$ & $22.14^{\mathrm{c}}$ & $16.93^{d}$ & $552.67^{\mathrm{ab}}$ \\
\hline 12 & $20.99^{a}$ & $59.00^{\text {bc }}$ & $23.71^{b}$ & $17.29^{\mathrm{cd}}$ & $556.60^{a}$ \\
\hline 16 & $20.05^{e}$ & $58.03^{c}$ & $23.51^{b}$ & $18.45^{\mathrm{ab}}$ & $549.27^{b c}$ \\
\hline 20 & $19.32^{f}$ & $59.53^{b}$ & $22.19^{c}$ & $18.28^{\mathrm{abc}}$ & $545.20^{c}$ \\
\hline SE & 0.000 & 0.381 & 0.148 & 0.329 & 1.861 \\
\hline $\operatorname{Pr}>\mathrm{F}$ & $<.0001$ & $<.0001$ & $<.0001$ & 0.0071 & 0.003 \\
\hline
\end{tabular}

Means in the same column having different small letters differ significantly $(P \leq 0.05)$

\section{Indices of body:}

Data in Table (5) showed that heptosomatic index (HSI) and intestine somatic index (ISI) of Nile tilapia fingerlings were significantly different $(\mathrm{P} \leq$ 0.05 ) among different levels of DDGS. The highest values of HIS and ISI were observed with the level of $12 \%$ DDGS( diet 4).

Table (5): Hepatosomatic index (HSI) and intestine somatic index (ISI) of Nile tilapia fingerlings fed different levels of DDGS

\begin{tabular}{|l|c|c|c|c|c|c|c|c|}
\hline \multirow{3}{*}{ Traits } & \multicolumn{6}{|c|}{ Levels of ( DDGS ) \% } & \multirow{2}{*}{ SE } & \multirow{2}{*}{ Pr $>$ F } \\
\cline { 2 - 9 } & 0 & 4 & 8 & 12 & 16 & 20 & & \\
\hline HIS & $1.97^{\mathbf{b c}}$ & $1.69^{\mathrm{c}}$ & $1.18^{\mathrm{d}}$ & $2.32^{\mathrm{a}}$ & $2.22^{\mathrm{ab}}$ & $1.71^{\mathrm{c}}$ & $\mathbf{0 . 0 8 7}$ & $\mathbf{0 . 0 0 5 4}$ \\
\hline $\mathbf{I S I}$ & $3.13^{\mathbf{b}}$ & $3.78^{\mathrm{b}}$ & $3.92^{\mathbf{b}}$ & $5.38^{\mathrm{a}}$ & $3.94^{\mathrm{b}}$ & $4.09^{\mathrm{b}}$ & $\mathbf{0 . 3 0 1}$ & $<.0001$ \\
\hline
\end{tabular}

Means in the same column having different small letters differ significantly ( $\leq \leq 0.05)$

Blood profile:

Data of blood hematological and biochemical parameters are given in Table (6) . The results cleared that there were no significant $(P \geq 0.05)$ differences among means of blood hematological parameters compared with the control, except those of mean corpuscular volume (MCV) red blood cells (RBCs) which were significant among different treatments. The RBCs value was significantly $(P \geq 0.05)$ the highest in the diet containing $4 \%$ of DDGS compared with other ones. On the other hand, the MCV values were the lowest $(P \geq 0.05)$ in the diets containing $12 \%$ and $16 \%$ of DDGS. The highest value of MCV was observed at the level $16 \%$ of DDGS. 
Table (6): Blood parameters of Nile tilapia fingerlings fed different levels of DDGS

\begin{tabular}{|c|c|c|c|c|c|c|c|c|}
\hline \multirow{2}{*}{ Traits } & \multicolumn{6}{|c|}{ Levels of (DDGS)\% } & \multirow{2}{*}{ SE } & \multirow{2}{*}{$\mathrm{Pr}>\mathrm{F}$} \\
\hline & 0 & 4 & 8 & 12 & 16 & 20 & & \\
\hline $\mathrm{Hb}(\mathrm{g} / \mathrm{dl})$ & 4.65 & 6.25 & 5.3 & 5.5 & 6.45 & 5.95 & 0.506 & 0.167 \\
\hline $\begin{array}{l}\text { RBCs }\left(\times 10^{6} \mathrm{~mm}^{-}\right. \\
3)\end{array}$ & $1.19^{b}$ & $2.27^{a}$ & $2.05^{a}$ & $1.33^{b}$ & $1.39^{b}$ & $1.70^{\mathrm{ab}}$ & 0.179 & 0.006 \\
\hline $\begin{array}{l}\text { WBCs }\left(\times 10^{3} \mathrm{~mm}^{-}\right. \\
3)\end{array}$ & 128.5 & 153 & 161.8 & 100.2 & 105.8 & 106 & 52.29 & 0.135 \\
\hline Hematocrit \% & 15.25 & 19.35 & 17.5 & 14 & 17 & 15.85 & 1.559 & 0.276 \\
\hline $\operatorname{MCV}\left(\square^{3}\right)$ & $129.0^{a}$ & $83.6^{\mathrm{cd}}$ & $80.6^{d}$ & $108.3^{\mathrm{abc}}$ & $122.5^{\mathrm{ab}}$ & $98.0^{\text {bcd }}$ & 7.927 & 0.004 \\
\hline MCH (pg) & 38.3 & 27.1 & 25.3 & 44.07 & 44.6 & 38.2 & 4.93 & 0.065 \\
\hline $\operatorname{MCHC}(\%)$ & 36.4 & 32.5 & 32.5 & 39.5 & 37 & 38.4 & 2.563 & 0.316 \\
\hline
\end{tabular}

Means in the same column having different small letters differ significantly $(P \leq 0.05)$.

\section{Economic efficiency:}

The results in Table (6) indicated that total outputs, net return, economic efficiency and relative economic efficiency were gradually increased with the increasing the level of DDGS up to $16 \%$ and then decreased at $20 \%$ DDGS. The total outputs, net return, economic efficiency and relative economic efficiency were the highest for the level of $16 \%$ of DDGS. Also, the levels $12 \%$ and $16 \%$ of DDGS gave the lowest total feed costs.

Table (7): Economic efficiency parameters of Nile tilapia fingerlings fed different levels of DDGS

\begin{tabular}{|c|c|c|c|c|c|c|c|c|}
\hline \multirow[b]{2}{*}{ Traits } & \multicolumn{6}{|c|}{ Levels of DDGS (\%) } & \multirow[b]{2}{*}{ SE } & \multirow[b]{2}{*}{$\mathrm{Pr}>\mathrm{F}$} \\
\hline & 0 & 4 & 8 & 12 & 16 & 20 & & \\
\hline Total outputs $^{1}$ & $0.447^{b c}$ & $0.397^{c}$ & $0.449^{\mathrm{bc}}$ & $0.469^{\mathrm{ab}}$ & $0.517^{\mathrm{a}}$ & $0.448^{\mathrm{bc}}$ & 0.018 & 0.018 \\
\hline Total feed costs ${ }^{2}$ & $0.127^{a}$ & $0.127^{a b}$ & $0.128^{a}$ & $0.111^{\mathrm{b}}$ & $0.112^{b}$ & $0.107^{b}$ & 0.004 & 0.023 \\
\hline Net return $^{3}$ & $0.319^{b c}$ & $0.279^{c}$ & $0.321^{\mathrm{bc}}$ & $0.357^{\mathrm{ab}}$ & $0.405^{\mathrm{a}}$ & $0.340^{b}$ & 0.016 & 0.003 \\
\hline $\begin{array}{l}\text { Economic } \\
\text { efficiency }{ }^{4}(\%)\end{array}$ & $250.8^{c}$ & $237.5^{c}$ & $249.2^{\mathrm{cf}}$ & $323.6^{\mathrm{ab}}$ & $361.4^{\mathrm{a}}$ & $315.6^{b}$ & 12.87 & 0.0001 \\
\hline $\begin{array}{l}\text { Relative econom } \\
\text { efficiency }\end{array}$ & $100^{c}$ & $94^{c}$ & $99^{c}$ & $128^{a b}$ & $144^{a}$ & $125^{b}$ & 5.022 & 0.0001 \\
\hline
\end{tabular}

Means in the same column having different small letters differ significantly $(P \leq 0.05)$.

Total cost of feed intake $(L E)=$ feed costs per one $\mathrm{kg}$ diet $X$ feed intake

1- Total outputs per treatment $(L E)=$ fish price $X$ total fish production ${ }^{*}$

2- Total fish production per treatment $=$ final number of fish $X$ fish weight

3- Net return per treatment $(\mathrm{LE})=$ total outputs - total feed costs

4- Economic efficiency per treatment $(\%)=$ (net return/ total feed costs) $X 100$

\section{DISCUSSION}

The obtained results indicated that most of growth performance (FW, WG, DAG, RGR and SGR) and feed utilization (FCR, FE, PER, PPV and EU) parameters were improved significantly $(P \leq 0.05)$ with increasing the replacement level of DDGS up to $16 \%$ of DDGS. However, no significant differences among the control diet and $20 \%$ of DDGS were observed. The highest values of growth performance parameters were found at the replacement levels $16 \%$ of DDGS. These results are in agreement with those 
Gabr, A. A. et al.

of Wu, et al. (1994 and 1995) who reported that diets containing corn gluten meal $18 \%$ or corn distillers grains with solubles $29 \%$ and $32 \%$ or $36 \%$ protein resulted in higher weights of tilapia than fish fed a commercial fish feed containing $36 \%$ protein and fish meal for tilapia. In this respect, Wu, et al. (1996) reported that the growth response of Nile tilapia (Oreochromis niloticus) fed diets containing $16-49 \%$ DDGS resulted in good WG (weight gain), FCR (Feed conversion ratio), and PER(Protein efficiency ratio). Tidwell, et al. (2000) compared the growth of Nile tilapia (Oreochromis niloticus) raised in cages fed either a sinking DDGS pellet or a sinking commercial catfish (Ictalurus punctatus) diet. The results showed that fish received the catfish diet grew $25 \%$ faster, cost of gain was $43 \%$ lower for fish fed the DDGS pellets. The authors concluded that an efficient and economical tilapia growth can be obtained using direct feeding of DDGS in situations where optimal growth is not essential.

Also, Lim and Webster (2006) found that 20\% fuel-based DDGS can be included in Nile tilapia diets without a significant effect on overall growth performance. However, fish fed diets containing 30\% DDGS had similar WG, PER and feed efficiency ratio (FER) as those fed the control diet, while fish fed $40 \%$ DDGS had significantly lower WG, PER and PER than those on the control diet. Vy (2006) found after 4 months culture period, the best growth rates of red tilapia were obtained in the fish fed $10 \%$ and $15 \%$ DDGS. The lowest growth rate was presented in the 0\% DDGS diet. The lowest FCR of the whole culture period were obtained at 15\% DDGS. On the other hand, Hung (2007) indicated that DDGS can be fed to growing common carp up to $15 \%$; however there is an indication that the feeding at $10-15 \%$ gave a faster growth rate than that fed 0 and $5 \%$.

The results in the presnt study indicated that HSI and ISI values were significantly differed $(P \leq 0.05)$ among different levels of DDGS. The highest values of $\mathrm{HSI}$ and ISI were observed at the level $12 \%$ of DDGS. Meanwhile, Schaeffer et al (2009) showed that the hepatosomatie indices did not significantly differ between fish fed $20 \%$ DDGS and the reference diets. The variation in the inclusion levels reported could be attributed to a number of factors such as species, fish age or size, source and quality of the tested ingredients, composition and nutrient content of the experimental diets, supplementation of limiting nutrients such as essential amino acid, culture system, feeding management and experimental conditions (Lim and YildrimAkosy, 2008 and Tangendjaja, 2008 ).

Finally, It appears that the current processing techniques of fuelbased DDGS did not yet provide any significant benefits over older beveragebased DDGS. Even though studies have shown increasing trends in protein and lipid levels of DDGS (Spiehs et al., 2002 and Belyea, et al., 2004) which should be beneficial to aquaculture diets. The current study indicated that fish fed lower levels of DDGS (20\%) had similar growth responses as those fed a fishmeal-based commercial diet, while studies using older DDGS had similar results using higher amounts of DDGS (>35\%) (Wu et al., 1996 and 1997).

In this study, there were no significant differences in survival of tilapia fed the six diets. Overall, survival was high and ranged from 90 to $100 \%$. These results are in agreement with those of Vy (2006) and Hung 
(2007) with O. niloticus and Webster, et al. (1992 a\&b) with channel catfish. Coyle et al. (2004) found no significant differences in survival of tilapia, overall, means of survival was high and ranged from 96.4 to $100 \%$. Abo-State et al. (2009) showed no significant differences survival rate among tilapia fed diets containing different levels of DDGS $(0,25,50,75$ and $100 \%)$. Survival rate was approximately $100 \%$ for fish fed all diets. In contrast, previous study of feeding DDGS to tilapia indicated an improvement on survival rate when DDGS was included in the diet (Tangendjaja and Chien., 2007).

Concerning the chemical composition of fish body, the results indicated that energy content (\%) of fish body did not significantly $(P \leq 0.05)$ differ with increasing DDGS levels up to $12 \%$ then decreased thereafter. The crude ash and fat increased significantly $(P \leq 0.05)$ with increasing DDGS levels. In the same trend, the crude protein was significant $(P \leq 0.05)$ among treatments. The highest value of DM and EC percentage observed in fish fed the levels of $12 \%$ DDGS. The present results agreed with those reported for many authers. In this respect, VY (2006) found after 4 months culture period, that there is no different in the composition of the fish after feeding diets containing different levels of DDGS. Also, Hung (2007) indicated that there is no different in composition of the fish after feeding diets containing different levels of DDGS.

Salama et al. (2011) found that fish fed diet containing $100 \%$ of DDGS recorded the highest values of $E E$ and conversely with protein content. The fish fed $100 \%$ DDGS recorded the highest value of ether extract while fish fed $50 \%$ DDGS recorded the lowest values. The research results indicated that total outputs, net return, economic efficiency and relative economic efficiency were gradually increased with the increasing the levels of DDGS in tested diets.

Aquaculture diet costs can account for over $50 \%$ of production with considering that protein is the most expensive dietary constituent (Coyle et at., 2004). The results in the present research indicated that the total outputs, net return, economic efficiency and relative economic efficiency were gradually increased with the increasing levels of DDGS until levels $16 \%$, and then decreased with increasing of DDGS level. The total outputs, net return, economic efficiency and relative economic efficiency were the highest for the level $16 \%$ of DDGS which showed also the lowest total feed costs.

These results are in agreement with Schaeffer et al, (2010) who reported that fishmeal may be replaced with low levels of fuel-based DDGS to reduce feeding cost; however, additional supplements should be considered to enhance fish performance. Because of the rising cost and uncertain availability of fishmeal from over-fished marine stocks, researchers have begun to investigate alternative protein sources (Jauncey and Ross, 1982; Fontaınhas-Fernandes et al., 1999 and Coyle et al., 2004). One plant nutrient source available for aquaculture feeds is distillers dried grains with solubles (DDGS) (Webster et al., 1992a,b, 1993; Wu et al., 1996, 1997; Coyle et al., 2004 and Lim and Webster., 2006). Tidwell et al. (2000) concluded that an efficient and economical tilapia growth can be obtained using direct feeding of DDGS in situations where optimal growth is not essential. These results agreed with the use of plant derived protein sources cheaper than SBM could 
be explored to further reduce the cost of fish feeds (Amayaet et al. 2007). The increasing price of feed is considered one of the most important factors limiting profitability in fish culture. The high cost of fish feed mainly due to the high costs of fish meal and SBM and therefore finding a relatively lower cost alternative ingredient was the ongoing research goal (Fomter et al. 2003 and Hernndez et al. 2008).

It may be concluded that replacing fish meal and yellow corn by DDGS until $16 \%$ in the diets of tilapia had no any adverse effect on most of growth parameters, feed utilization, chemical composition of fish body, hematological blood parameters and economic efficiency of tilapia fingerlings.

\section{REFERENCES}

Abo-State, H.A., Tahoun, A. and Hammouda, Y.A. (2009). Effect of replacement of soybean meal by DDGS combined with commercial phytase on Nile tilapia (Oreochromis niloticus) fingerlings growth performance and feed utilization. American-Eurasian J. Agric. \& Environ. Sci., 5 (4): 473-479.

Amayaet, E.A., Davis, D.A. and Roase, D.B. (2007). Replacement of fish meal in practical diets for the Pacific white shrimp (Litopenaeus vannamet) reared under pond conditions. Aquaculture 262: 393-401.

AOAC (2000). Association of Official Analytical Chemists of Official Methods of Analysis, 17th Ed. Washington, DC.

Belyea, R.L.; Rausch, K.D. and Tumbleson, M.E. (2004). Composition of corn and distillers dried grains with solubles from dry grind ethanol processing. Bioresour. Technol., 94: 293-298.

Brown, P.B.,Twibell R., Jonker Y. and Wilson K.A. (1997) Evaluation of three soybean products in diets fed to juvenile hybrid striped bass Morone saxatilis _ M. chrysops. Journal of the World Aquaculture Society 28, 215-223.

Coyle, S. D., Mengel, G. J., Tidwell, J. H. and Webster, C. D. (2004). Evaluation of growth, feed utilization and economics of hybrid tilapia, Oreochromis niloticus $x$ Oreochromis aureus, fed diets containing different protein sources in combination with distillers dried grains with solubles. Aquaculture Research 35:1-6.

Dacie, J. V. and Lewis, S. M. (1995). Practical Haematology. 8th ed. Edinburgh, Scotland: Churchill Livingstone.

Duncan, D.B. (1955). Multiple ranges and multiple f-tests . Biometrics 11:142.

El-Sayed, A.M. (1990) Long-term evaluation of cotton seed meal as a protein source for Nile tilapia, Oreochromis niloticus (Linn.). Aquaculture 84:315-320.

Fontaínhas- Fernandes, A., E. Gomes, M. A. Reis-Henriques, and Coimbra, J. (1999). Replacement of fish meal by plant proteins in the diet of Nile tilapia: digestibility and growth performance. Aquaculture International 7:57-67. 
Francis, G. Makkar H.P.S. and Becker, K. (2001). Antinutritional factors present in plant derived alternate fish feed ingredients and their effects in fish. Aquaculture 199:197-227.

Fomter, I.P., Dominy, W., Obaldo, L. and Tacon, A.G.1. (2003). Rendered meat and bone meals as ingredients of diets for shrimp Litopenaeus vannamet (Boone, 1931). Aquaculture 219: 655-670.

Hardy, R.W (2010). Utilization of plant proteins in fish diets: effects of global demand and supplies of fishmeal. Aquaculture Research 41, 770-776.

Hernndez, C., Olvera-Novoa, M.A., Aguilar-Vejar, K., Gonzalez-Rodriguez, B. and Parra, I. A (2008). Partial replacement of fish meal by porcine meat meal in practical diets for Pacific white shrimp (Litopenaeus vannamet). Aquaculture, 277: 244-250.

Hung, L. K. (2007). Use of DDGS for feeding Common Carp under commercial condition. Final Report of U.S. Grains Council , South East Asia.

Jangaard, P.M., Brockerhoff, H., Burghe r, R.D. and Hoyle, R.J. (1967). Seasonal changes in general condition and lipid content of cod from inshore waters. Fish. Res. Board Can. 24:607-612.

Jackson, A.J. Capper B.S. and Matty, A.J. (1982). Evaluation of some plant proteins in complete diets for the tilapia Sarotherodon mossambicus. Aquaculture 27:97-109.

Jauncey, K. and Ross, B.R. (1982). A guide to tilapia feeds and feeding. Institute of Aquaculture, University of Stirling, Scotland.

Lim, C. (1989) Practical feeding-tilapias. In: Nutrition and Feeding of Fish (ed. byT. Lovell), pp.163-176. Van Nostrand Reinhold, New York, NY, USA.

Lim, C. and Webster, C. D. (2006). Nutrient requirements. Page 469-501 in C. Lim and Webster, C.D. editors. Tilapia Biology, Culture, and Nutrition. The Haworth Press, Inc., New York, New York, USA.

Lim, C. and Yildrim-Akosy, M., (2008). Distillers dried grains with solubles as an Alternative protein source in fish feeds. 8th International Symposium on Tilapia in Aquaculture, October 12-14, 2008, Cairo, Egypt. p. 67-82.

Lim, C., Yildirim-Aksoy, M. and Klesius, P.R. (2009). Growth response and resistance to Edwardsiella ictaluri of channel catfish (Ictalurus punctatus) fed diets containing distiller's dried grains with solubles. I. the World Aquaculture Society. 40: 182-193.

NRC (National Research Council), (1993). Nutrient Requirements of Fish. National Academy of Science, Washington, DC, $141 \mathrm{pp}$.

SAS (2006). SAS/ STAT Guide for personal computer. SAS Institute Inc., Cary, NC, USA.

Salama, F.A.; Tonsy, H.D.; Labib, E.M.; Mohmoud, S.H. and Zaki, M.A. (2010). Nutritional studies on partial and total replacment of soybean meal by distillers dried grains with soluble (DDGS) in diets for Nile tilapia (Oreochromis niloticus). Egyptian J. Nutrition and Feeds 13 (1): $165-176$.

Salama, F.A., All, M.N., Mahmoud, S.H., Hayam D. T. and Hasouna, M.M.E. (2011). Effects of radish root extract on improving the utilization of corn dried distillers grains with solubles in Nile tilapia (Oreochromis niloticus) fry diets. American-Eurasian J. Agric. \& Environ. Sci. (6): 938-946. 
Gabr, A. A. et al.

Schaeffer, T. W., Brown, M. L. and Rosentrater, K. A. (2009). Performance characteristics of Nile tilapia (Oreochromis nitoticus) fed diets containing graded levels of fuel-based distifiers dried grains with solubles. Journal of Aquaculture Feed Science and Nutrition 1(4): 78 83.

Schaeffer1, T. W., Brown, M. L., Rosentrater, K. A. and Muthukumarappan, K. (2010). Utilization of diets containing graded levels of ethanol production co-products by Nile tilapia. Journal of Animal Physiology and Animal Nutrition, 94 ; e348-e354.

Spiehs, M.J., Wbitney, M.H. and Shurson, G.C. (2002). Nutrient database for distillers dried grains with solubles produced from new ethanol plants in Minnesota and South Dakota. J. Anim. Sci. 80: 2639-2645.

Stoskopf, M. K. (1993). Fish Medicine. W.B. Saunders Company Harcour Brace Lovanovish, Inc.

Tangendjaja, B and Chien,T.T. (2007). Use of Dried Distiller Grain and Solubles (DDGS) for feeding tilapia. Proc. IndoAqua Bali, July 30August 1.

Tangendjaja, B. (2008). Update on DDGS quality consideration $16^{\text {th }}$ Annual ASA-IM Sea Feed Technology and Nutrition Workshop Singapore.

Tidwell, J.H.; Coyle S.D.;Van Arnum, A.;Weibel C. and Harkins, S. (2000). Growth, survival, and body composition of cagecultured Nile tilapia Oreochromis niloticus fed pelleted and unpelleted distillers grains with solubles in polyculture with freshwater prawn Macrobrachium rosenbergii. Journal of the World Aquaculture Society 31:627-631

Twibell, R.G. and Brown P.B. (1998). Optimal dietary protein concentration for hybrid tilapia Oreochromis niloticus $O$. aureus fed all-plant diets. Journal of the World Aquaculture Society 29:9-16.

VY, L. H. (2006). Use of DDGS for feeding red tilapia under Vietnam condition. Final Report of U.S. Grains Council , South East Asia.

Webster, C. D.; Tidwell, J. H.; Goodgame, L. S.; Clark, J. A.; and Yancey, D. H., (1992a). Winter feeding and growth of channel catfish fed diets containing varying percentages of distillers grains with solubles as a total replacement of fishmeal. Journal of Applied Aquaculture 1:1-4.

Webster, C. D.; Tidwell, J. H.; Goodgame, L. S.; Yancey, D. H.; and Mackey, L., (1992b). Use of soyabean meal and distillers grains with solubles as partial or total replacement of fishmeal in diets for channel catfish, Ictalurus punctatus. Aquaculture 106: 301-309.

Webster, C. J., Tidwell, J. H., Goodgame, L. S. and Johnsen, P. B. (1993). Growth, body composition, and organoleptic evaluation of channel catfish fed diets containing different percentages of distiller's grain with solubles. Progressive Fish-Culturist 55:95-100.

Webster C.D., Thompson, K.R., Morgan, A.M., Grisby, E.J. and Gannam, A.L. (2000) Use of hempseed meal, poultry byproduct meal, and canola meal in practical diets without fish meal for sunshine bass (Morone chrysops_ M. saxatilis). Aquaculture 188: 299-309.

Wu, Y. V.; Rosati, R.; Sessa, D. J. and Brown, P. (1994). Utilization of protein-rich ethanol co-products from corn in tilapia feed. J. Am. Oil Chem. Soc., 71:1041-1043. 
Wu, Y. V.; Rosati, R. R.; Sessa, D. J. and Brown, P. B. (1995). Evaluation of corn gluten meal as a protein source in tilapia diets. J. Agric. Food Chem., 43: 1585-1588. Received for review November 6, 1995. Revised manuscript.

Wu, Y.V.;Warner K.; Rosati, R.; Sessa, D.J. and Brown, P. (1996). Sensory evaluation and composition of tilapia (Oreochromis niloticus) fed diets containing protein-rich ethanol by-products from corn. Journal of Aquatic Food Product Technology 5:7-16.

Wu, Y. V., Rosati, R. R. and Brown, P. B. (1996). Effect of diets containing various levels of protein and ethanol coproducts from corn on growth of tilapia fry. Journal of Agricultural Food Chemistry 44:1491-1493.

Wu, Y. V., Rosati, R. R. and Brown, P. B. (1997. Use of corn-derived ethanol coproducts and synthetic lysine and tryptophan for growth of tilapia (Oreochromis niloticus) fry. Journal of Agricultural Food Chemistry 45:2174-2177.

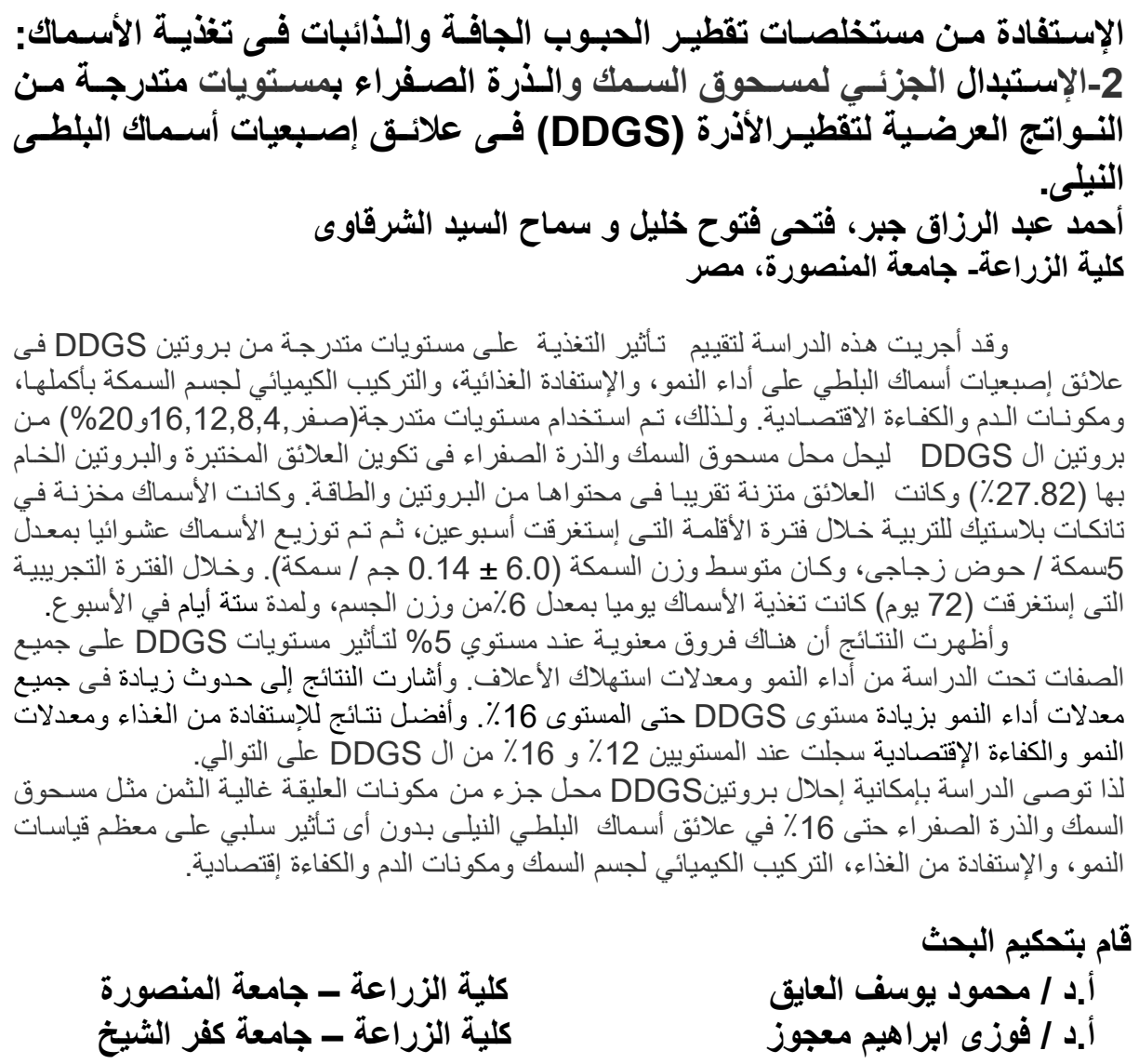

